Bangladesh J. Plant Taxon. 20(1): 77-83, 2013 (June)

(C) 2013 Bangladesh Association of Plant Taxonomists

\title{
NUMERICAL TAXONOMY OF THE GENUS SENNA MILL. FROM BANGLADESH
}

\author{
M. Oliur Rahman ${ }^{1}$, Md. Zahidur Rahman and Ayesa Begum \\ Department of Botany, University of Dhaka, Dhaka 1000, Bangladesh
}

Keywords: Senna; Cluster analysis; Phenetic relationship; UPGMA.

\begin{abstract}
This study examines the patterns of morphological variation and phenetic relationships among 11 species of Senna Mill. from Bangladesh using 32 vegetative and floral characters. The highest similarity is found between S. obtusifolia and S. tora, while the highest variation is observed between $S$. alata and $S$. hirsuta. UPGMA tree derived from cluster analysis reveals three major clusters, the first of which consists of two species (S. alata and S. auriculata), the second cluster comprises four species (S. hirsuta, S. obtusifolia, S. tora and S. occidentalis) and the third one is composed of five species (S. multiglandulosa, S. sophera, S. siamea, S. timoriensis and S. surattensis). A close relationship is also found between $S$. multiglandulosa and $S$. sophera, and between $S$. siamea and $S$. timoriensis. Results obtained from the present study are found congruent with cytological and anatomical studies showing the significance of numerical analysis for taxonomic relationship in the genus Senna.
\end{abstract}

\section{Introduction}

Numerical taxonomy, also termed as morphometrics deals with grouping by numerical methods of taxonomic units into taxa on the basis of their character state (Sneath and Sokal, 1973). Cluster analysis and principal component analysis are two techniques commonly used in numerical classification. Cluster analysis produces a hierarchical classification of entities (taxa) based on the similarity matrix. It thus provides a logical means of expressing the relationship existing between taxa. Numerical taxonomic studies are important for discovering and documenting new morphological character and character states, and many attempts have been made in this regard for understanding phenetic relationships in different groups of plants (Pinheiro and de Barros, 2007; Mulumba and Kakudidi, 2010; Deshmukh, 2011; Rahman and Rahman, 2012).

The genus Senna Mill. (Caesalpiniaceae) is represented by 350 species and is distributed throughout the world (Marazzi et al., 2006). Irwin and Barneby (1982) reports that about $80 \%$ of the Senna species are found in the American continent, while most of the remaining members occur in tropical Africa, Madagascar and Australia, with only a few species in southeastern Asia and the Pacific Island. Senna are characterized by the presence of cylindrical or flattened, irregularly dehiscent pods and longest filaments without sigmoidally curved towards the base and seed surfaces usually with areole. Economically Senna species are very important since their bark and oil extract are used for flavouring purposes and in soaps, candy and perfumery (Hill, 1952). Several Senna species are reported to have medicinal properties as laxative, expectorant, antimalarial, relaxant and anti-inflammatory (Sadique and Chandra, 1987; Ajagbonna and Mojiminiyi, 2001; Tona and Mesia, 2001).

Studies on the genus Senna are very much limited in Bangladesh. Baker (1879) described 18 species of Cassia s.l. of which 6 species now included in Senna are found in the area of Bangladesh. Prain (1903) listed 7 species of Senna from the then Bengal which falls under the

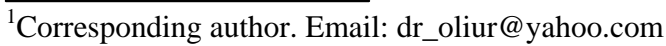


territory of present Bangladesh. Although Khan et al. (1996) documented 6 species of the Senna from Bangladesh, recently Ahmed et al. (2008) reported 10 species of the genus from the country. The extensive field surveys through the present study revealed a total of 11 species of Senna are now found in Bangladesh. Despite few fragmentary studies are available on Senna, numerical approaches have never been tested in this genus to determine species relationships. Therefore, the present study aims at applying numerical method for examining morphological variation and inferring phenetic relationships among Senna species occurring in Bangladesh.

\section{Materials and Methods}

Plant materials:

Eleven species of Senna were used in the present study (Table 1). Both fresh materials collected from different areas of Bangladesh, and herbarium specimens housed at Dhaka University Salar Khan Herbarium (DUSH) and Bangladesh National Herbarium (DACB) were examined for numerical analysis.

Table 1. List of Senna species along with their vouchers used in the present study.

\begin{tabular}{|c|c|c|}
\hline No. & Species & Specimens examined \\
\hline 1 & $\begin{array}{l}\text { Senna alata }(\mathrm{L} .) \\
\text { Roxb. }\end{array}$ & $\begin{array}{l}\text { Bandarban: Chimbuk hills, Mirzapara, 27.11.1983, Khan, Huq, Rahman \& } \\
\text { Mia K. } 6494 \text { (DACB); Dhaka: Dhaka University campus, 23.12.2011, } \\
\text { Ayesa } 65 \text { (DUSH). }\end{array}$ \\
\hline 2 & S. auriculata L. & $\begin{array}{l}\text { Dhaka: Shere-e-Bangla Agricultural University compound, 26.1.2011, } \\
\text { Ayesa } 07 \text { (DUSH); Sangshad Bhaban, 27.1.2011, Ayesa } 08 \text { (DUSH). }\end{array}$ \\
\hline 3 & $\begin{array}{l}\text { S. hirsuta (L.) Irwin } \\
\text { \& Barneby }\end{array}$ & $\begin{array}{l}\text { Bandarban: Lama, 6.12.2007, Bushra, Halib \& Mafiz B } 609 \text { (DACB); } \\
\text { Cox’s Bazar: Bamiachara near Chakaria, 2.12.1999, Khan, Mia, Rashid \& } \\
\text { Islam K. } 10177 \text { (DACB); Gazipur: Gazipur, 30.6.2011, Ayesa } 40 \text { (DACB). }\end{array}$ \\
\hline 4 & $\begin{array}{l}\text { S. multiglandulosa } \\
\text { (Jacq.) Irwin \& } \\
\text { Barneby }\end{array}$ & No fresh or herbarium specimens available. \\
\hline 5 & $\begin{array}{l}\text { S. obtusifolia }(\mathrm{L} .) \\
\text { Irwin \& Barneby }\end{array}$ & $\begin{array}{l}\text { Bandarban: Chimbuk hills, 26.11.1983, Khan, Huq, Rahman \& Mia K. } \\
6472 \text { (DACB); Cox’s Bazar: Teknaf, Mouchuni, 24.4.2011, Ayesa } 32 \\
\text { (DUSH); Patuakhali: Islampur, 6.2.2011, Ayesa } 17 \text { (DUSH). }\end{array}$ \\
\hline 6 & $\begin{array}{l}\text { S. occidentalis } \\
\text { Roxb. }\end{array}$ & $\begin{array}{l}\text { Bogra: Mohasthangarh, 22.8.1989, Mia, Rahman, Mahbuba \& Rezia M } \\
2117 \text { (DACB); Dhaka: Dhaka University campus, 26.12.2010, Ayesa } 02 \\
\text { (DUSH); Gazipur: Rajendrapur forest, 22.12.2011, Ayesa } 63 \text { (DUSH). }\end{array}$ \\
\hline 7 & $\begin{array}{l}\text { S. siamea (Lamk.) } \\
\text { Irwin \& Barneby }\end{array}$ & $\begin{array}{l}\text { Chittagong: Chunati range, 10.6.1979, Khan, Huq \& Rahman K } 5515 \\
\text { (DACB); Dhaka: Tejgaon, Old Airport, 27.12.2011, Ayesa } 74 \text { (DUSH). } \\
\text { Panchagarh: Fakirhat, 30.6.1998, Mia et al. M } 3883 \text { (DACB). }\end{array}$ \\
\hline 8 & $\begin{array}{l}\text { S. sophera (L.) } \\
\text { Roxb. }\end{array}$ & $\begin{array}{l}\text { Chittagong: Sandwip, Rahmatpur 12.2.1988, Mia and Mahfuz M } 1590 \\
\text { (DACB); Cox’s Bazar: Teknaf, Shilkhali, 30.2. 2011, Ayesa } 25 \text { (DUSH); } \\
\text { Dhaka: Dhaka University Campus, 30.4.11, Aeysa } 33 \text { (DUSH). }\end{array}$ \\
\hline 9 & $\begin{array}{l}\text { S. surattensis } \\
\text { (Burm. f) Irwin \& } \\
\text { Barneby }\end{array}$ & $\begin{array}{l}\text { Dhaka: Dhaka University campus, 20.12.2011, Ayesa } 47 \text { (DUSH); Div 22, } \\
\text { 19.10.1977, M. Naskar } 3955 \text { (DUSH). }\end{array}$ \\
\hline 10 & $\begin{array}{l}\text { S. timoriensis (DC.) } \\
\text { Irwin \& Barneby }\end{array}$ & $\begin{array}{l}\text { Bandarban: Ruma bazar, 28.10.1984, Khan, Huq, Rahman \& Mia K } 6724 \\
\text { (DACB); Chittagong Hill Tracts: Ruma P.S., Changnakra, 25.1.1965, M. S. } \\
\text { Khan } 1166 \text { (DUSH). }\end{array}$ \\
\hline 11 & S. tora (L.) Roxb. & $\begin{array}{l}\text { Dhaka: Dhaka University Botanical garden, 26.12.2011, Ayesa } 69 \text { (DUSH); } \\
\text { Khulna: Jatrapur Railways line side, 16.6.1982, A. M. Huq } 5542 \text { (DACB). }\end{array}$ \\
\hline
\end{tabular}




\section{Characters:}

Thirty two characters were investigated and used in this analysis. Characters and character states were determined through examination of both living and herbarium specimens housed at DUSH and DACB. Both qualitative and quantitative characters were coded as binary-state. The characters and their binary states used for numerical taxonomic studies are listed in Table 2. Neither herbarium nor living specimens of Senna multiglandulosa were available; therefore character states for this species were determined from the relevant literature (Ahmed et al., 2008).

\section{Statistical analysis:}

The data matrix was scored using binary matrix. Dissimilarity matrix was prepared based on the data matrix. Cluster analysis was performed using UPGMA (unweighted pair group method with arithmetic mean) and a dendrogram was constructed to show the relationship among the species (Sneath and Sokal, 1973). All analyses were carried out using the program STATISTICA (Version 3.0).

\section{Result and Discussion}

Thirty two vegetative and reproductive characters have been identified for numerical analysis of Senna species (Table 2).

Table 2. Morphological characters and their state used in the numerical analysis.

\begin{tabular}{lll}
\hline No. & Characters & Character states \\
\hline 1 & Habit & Herb or undershrub (1), Shrub or tree (0). \\
2 & Stem & Hairy (1), Glabrous (0). \\
3 & Leaves & 6-20 pairs (1), 2-5 pairs (0) \\
4 & Stipules & Persistent (1), Cauducous or subpersistent (0). \\
5 & Shape of stipules & Deltoid or ovate (1), Linear or cordate (0). \\
6 & Size of stipules & 1-5 mm (1), 8-20 mm (0). \\
7 & Leaf attachment & Alternate (1), Opposite (0). \\
8 & Petiole length & 0.1-0.3 cm (1), > 0.4 cm (0). \\
9 & Gland & Present (1), Absent (0). \\
10 & Laminar shape & Oblong or elliptic (1), Ovate or cordate (0). \\
11 & Base angle & Obtuse (1), Acute (0). \\
12 & Apex angle & Acute (1), Acumminate or obtuse (0). \\
13 & Base shape & Rounded or obtuse (1), Oblique or unequal (0). \\
14 & Apex shape & Rounded or obtuse (1), Acute or acumminate \\
15 & Margin type & Entire (1), Serrulate (0). \\
16 & Lobation of vein & Present (1), Absent (0). \\
17 & Inflorescence & Axillary and terminal (1), Terminal (0). \\
18 & Sepal & Free (1), United (0). \\
19 & Bract & Present (1), Absent (0). \\
20 & Shape of bract & Ovate (1), Linear to lanceolate (0). \\
21 & Bracteole & Present (1), Absent (0). \\
22 & Corolla & Free (1), United (0). \\
23 & Anther & Bilobed (1), Not bilobed (0). \\
\hline & &
\end{tabular}


Table 2 Contd.

\begin{tabular}{lll}
\hline No. & Characters & Character states \\
\hline 24 & Anther opening & Apical pore (1), Lateral (0). \\
25 & Ovary & Glabrous (1), Hairy (0). \\
26 & Stigma & Truncate (1), Punctiform or others (0). \\
27 & Shape of pod & Linear to curved (1); Oblong (0). \\
28 & Surface of pod & Pubescent (1), Glabrous (0). \\
29 & Number of seeds per pod & $>30(1), 6-12(0)$. \\
30 & Dehiscence of pod & Dehiscent (1), Indehiscent (0). \\
31 & Areole & Present (1), Absent (0). \\
32 & Seed shape & Ovoid or oblong (1), Rhomboidal (0). \\
\hline
\end{tabular}

The present study reveals that the lowest morphological variation is observed between $S$. obtusifolia and S. tora indicating that they are most closely related among all species studied. S. occidentalis is also very close to S. obtusifolia. The highest variation is found between S. alata and S. hirsuta (Table 3). A high variation has also been detected between S. alata and S. tora; and S. alata and S. obtusifolia.

Table 3. Morphological variation among 11 species of Senna based on Squared Euclidean distance.

\begin{tabular}{|c|c|c|c|c|c|c|c|c|c|c|c|}
\hline Species & alat & auri & hirs & mult & obtu & occi & siam & soph & sura & timo & tora \\
\hline alat & 0 & & & & & & & & & & \\
\hline auri & 9 & 0 & & & & & & & & & \\
\hline hirs & 18 & 13 & 0 & & & & & & & & \\
\hline mult & 10 & 9 & 14 & 0 & & & & & & & \\
\hline obtu & 15 & 10 & 9 & 13 & 0 & & & & & & \\
\hline occi & 12 & 13 & 8 & 10 & 5 & 0 & & & & & \\
\hline siam & 12 & 13 & 12 & 8 & 13 & 10 & 0 & & & & \\
\hline soph & 12 & 13 & 12 & 6 & 9 & 6 & 10 & 0 & & & \\
\hline sura & 14 & 11 & 12 & 10 & 9 & 12 & 10 & 10 & 0 & & \\
\hline timo & 11 & 10 & 11 & 11 & 12 & 13 & 7 & 13 & 9 & 0 & \\
\hline tora & 16 & 9 & 8 & 12 & 3 & 6 & 12 & 8 & 6 & 11 & 0 \\
\hline
\end{tabular}

alat $=$ Senna alata, auri $=S$. auriculata, hirs $=S$. hirsuta, mult $=S$. multiglandulosa, obtu $=S$. obtusifolia, occi $=S$. occidentalis, siam $=S$. siamea, soph $=S$. sophera, sura $=S$. surattensis, timo $=S$. timoriensis, tora $=S$. tora

The numerical analysis presents the phenetic relationships among 11 Senna species. The UPGMA dendrogram based on cluster analysis reveals three clusters. The first cluster consists of two species, viz. S. alata and S. auriculata; the second one comprises four species, namely $S$. hirsuta, S. obtusifolia, S. tora and S. occidentalis; while the third cluster includes five species, viz., S. multiglandulosa, S. sophera, S. siamea, S. timoriensis and S. surattensis (Fig. 1).

In the first cluster $S$. alata is grouped with $S$. auriculata indicating that they are closely allied, and this is evidenced by the presence of their puberulent stem, persistent stipule and linear to oblong pod. A close association between S. hirsuta, S. obtusifolia, S. tora and S. occidentalis is evident in the second cluster. The common characters shared by these four species include linear 
stipule, racemose inflorescence, orbicular to rhomboidal seeds and presence of glands on the rachis. In this cluster the highest similarity has been observed between S. obtusifolia and S. tora showing that they are most closely related among all the species studied, and this highest affinity is supported by the following shared characters: leaflets obovate, stipules linear, falcate, inflorescence short-racemose, axillary, ovary ribbed, style glabrous, stigma truncate, pod linear or subtetragonous and seeds are 4-5 mm long, with an areole on each face.

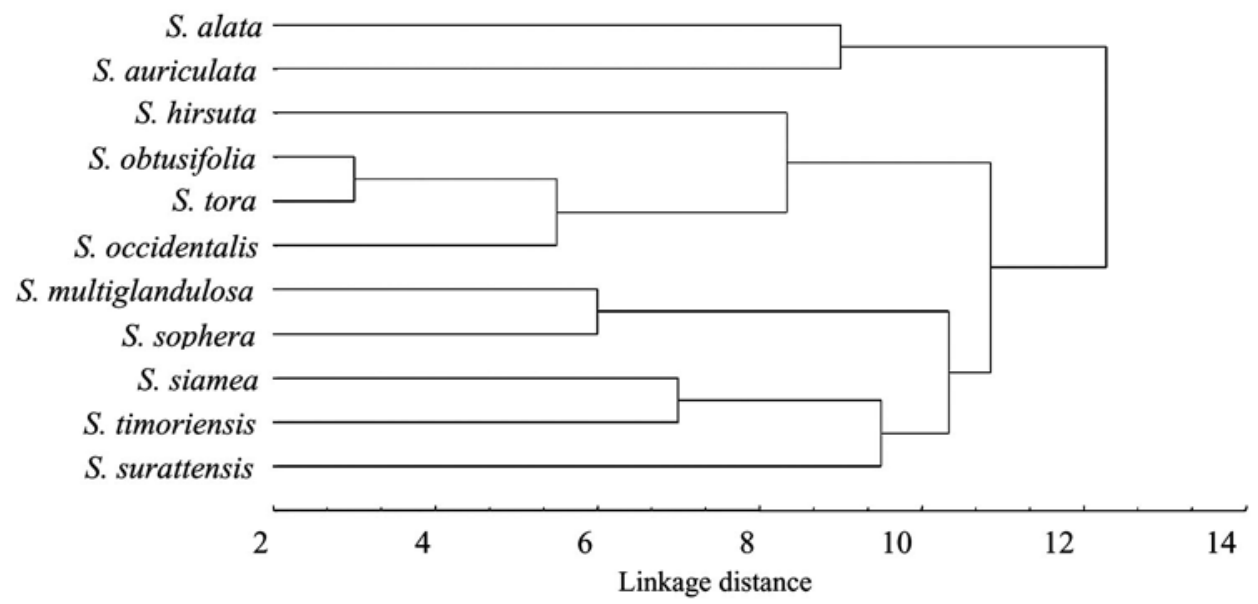

Fig.1. UPGMA dendrogram showing species relationship in Senna.

In the third cluster two distinct subclusters are found. The first one consists of $S$. multiglandulosa and $S$. sophera, and they are in the same line by presence of glandular leaves, ovate bracts, caducous stipule, pubescent ovary, and compressed, pointed seeds. The second subcluster contains S. siamea, S. timoriesnsis and S. surattensis. In this subcluster S. siamea and S. timoriensis are found to be more close to each other than they are to S. surattensis. Senna siamea and $S$. timoriensis both are evergreen trees and the close affinity between them is supported by their eglandular leaves, linear bracts, puberulent sepals, glossy brown seeds and presence of areoles.

Morphometric studies received considerable attention for species relatedness in different genera (Gomez-Campo et al., 2001; Henderson and Ferreira, 2002; Sonibare et al. 2004; Bolourian and Pakravan, 2011). Although such studies were carried out in different legume genera, for example, Cassia (Boonkerd et al., 2005), Indigofera (Soladoye et al., 2010a), Daniellia (de La Estrella et al. 2009), however very little is known about the morphometrics in the genus Senna. Recently Soladoye et al. (2010b) made a morphometric study of eight species of Senna from south-western Nigeria and using 13 morphological characters they showed that $S$. sophera is closely related to $S$. hirsuta. Our results suggest that $S$. sophera is closely allied to $S$. multiglandulosa which is incongruent with that of Soladoye et al. (2010b). The present study reveals a close association between S. hirsuta, S. obtusifolia, S. tora and S. occidentalis as they grouped together. Ogundipe et al. (2009) have shown that paracytic and anomocytic types of stomata are found both in S. hirsuta and S. occidentalis. The anticlinal walls are straight and undulate in both these species indicating a close relationship between them. Our result is supported by Ogundipe et al. (2009) since a close affinity has been observed between S. hirsuta, S. obtusifolia, S. tora and S. occidentalis. The close affinity among these species is also evidenced by 
cytological investigation where the somatic chromosome number $2 n=28$ was reported for these four species (Irwin and Turner, 1960; Bir and Kumari, 1980). In conclusion, our study shows the significance of numerical analysis for detecting variation and taxonomic relationships among Senna species available in Bangladesh as it is attested by previous studies based on cytological and anatomical characters.

\section{Acknowledgement}

The authors are thankful to the Director, Bangladesh National Herbarium, Dhaka for allowing to use herbarium facilities. Thanks are also due to Prof. Md. Abul Hassan and Prof. Momtaz Begum, Department of Botany, University of Dhaka for their help and cooperation during this study.

\section{References}

Ahmed, Z.U., Hassan, M.A. Begum, Z.N.T., Khondker, M., Kabir, S.M.M.H., Ahmed, M., Ahmed, A.T.A., Rahman, A.K.A. and Huque, E.U. (eds). 2008. Encyclopedia of Flora and Fauna of Bangladesh, Vol. 7. Angiosperms: Dicotyledons (Balsaminaceae-Euphorbiaceae). Asiatic Society of Bangladesh, Dhaka, 546 pp.

Ajagbonna, O.P. and Mojiminiyi, F.B.O. 2001. Relaxant effects of the aqueous leaf extract of Cassia occidentalis on rat aortic rings. African J. Biomed. Res. 4(3): 127.

Baker, J.G. 1879. In: Hooker, J.D., The Flora of British India, Vol. 2. Reeve \& Co. Ltd. England, pp. 261267.

Bir, S.S. and Kumari, S. 1980. Cytological evolution of the Leguminous flora of the Punjub plain. In: Bir, S.S. (ed.), Recent Researches in Plant Science. Kalyani Publishers, Ludhiana, India, pp. 261-271.

Bolourian, S. and Pakravan, M. 2011. A morphometric study of the annual species of Alyssum (Brassicaceae) in Iran based on their macro- and micromorphological characters. Phytologia Balcanica 17(3): 283-289.

Boonkerd, T., Pechsri, S. and Baum, B.R. 2005. A phenetic study of Cassia sansu lato (LeguminosaeCaesalpinioideae: Cassieae: Cassiinae) in Thailand. Plant Syst. Evol. 252: 153-165.

de La Estrella, M., Aedo, C. and Velayos, M. 2009. A morphometric analysis of Daniellia (FabaceaeCaesalpinioideae). Bot. J. Linn. Soc. 159: 268-279.

Deshmukh, S.A. 2011. Morphometrics of the genus Cassia L. from Kolhapur district. The Bioscan 6(3): 459-462.

Gomez-Campo, C., Herranz-Sanz, J.M. and Montero-Riquelme, F. 2001. The genus Coincya Rouy (Cruciferae) in South-central Spain revisited: A morphometric analysis of population structure. Bot. J. Linn. Soc. 135: 125-135.

Henderson, A. and Ferreira, E. 2002. A morphometric study of Synechanthus (Palmae). Syst. Bot. 27(4): 693-702.

Hill, F.A. 1952. Economic Botany. McGraw Hill Books Company, New York, 560 pp.

Irwin, H.S. and Barneby, R.C. 1982. The American Cassiinae. Mem. New York Bot. Gard. 35: 1-918.

Irwin, H.S. and Turner, B.L. 1960. Chromosomal relationships and taxonomic considerations on the genus Cassia. Am. J. Bot. 47(4): 309-318.

Khan, M.S., Khatun, B.M.R. and Rahman, M.M. 1996. A preliminary account of legume diversity in Bangladesh. Bangladesh J. Plant Taxon. 3(1): 1-33.

Marazzi, B., Endress, K.P., de Queiroz, L.P. and Conti, E. 2006. Phylogenetic relationships within Senna (Leguminosae, Cassiinae) based on three chloroplast DNA regions: Patterns in the evolution of floral symmetry and extrafloral nectaries. Am. J. Bot. 93(2): 288-303.

Mulumba, J.W. and Kakudidi, E. 2010. Numerical taxonomic study of Acacia senegal (Fabaceae) in the cattle corridor of Uganda. South African J. Bot. 76: 272-278. 
Ogundipe, O.T., Kadiri, A.B. and Adekanmbi, O.H. 2009. Foliar epidermal morphology of some Nigerian species of Senna (Caesalpiniaceae). Indian J. Sci. Technol. 2(10): 5-9.

Pinheiro, F. and de Barros, F. 2007. Morphometric analysis of Epidendrum secundum (Orchidaceae) in southeastern Brazil. Nordic J. Bot. 25: 129-136.

Prain, D. 1903. Bengal Plants, Vol. 1, Botanical Survey of India, Calcutta, India, pp.313-315.

Rahman, M.Z. and Rahman, M.O. 2012. A morphometric analysis of Desmodium Desv. (Fabaceae) in Bangladesh. Bangladesh J. Bot. 41(2): 143-148.

Sadique, J. and Chandra, T. 1987. Biochemical modes of action of Cassia occidentalis and Cardiospermum halicacabum in inflammation. J. Ethnopharmacol. 19: 201-212.

Sneath, P.H.A. and Sokal, R.R. 1973. Numerical Taxonomy, Freeman and Company, San Francisco, USA, $573 \mathrm{pp}$.

Soladoye, M.O., Sonibare, M.A. and Chukwuma, E.C. 2010a. Morphometric study of the genus Indigofera Linn. (Leguminosae-Papilionoideae) in South-western Nigeria. International J. Bot. 6(3): 343-350.

Soladoye, M.O., and Onakoya, M.A., Chukwuma, E.C. and Sonibare, M.A. 2010b. Morphometric study of the genus Senna Mill. in South-western Nigeria. African J. Plant Science 4(3): 44-52.

Sonibare, M.A., Jayeola, A.A. and Egunyomi, A. 2004. A morphometric analysis of the genus Ficus Linn. (Moraceae). African J. Biotechnol. 3(4): 229-235.

Tona, L. and Mesia, K. 2001. In vivo antimalarial activity of Cassia occidentalis, Morinda morindoides and Phyllanthus niruri. Ann.Trop. Med. Parasitol. 95: 47-57.

(Manuscript received on 15 November 2012; 24 February 2013) 